\title{
1MDB: The Background
}

\author{
Azham Md. Ali \\ Department of Accounting and Finance, Faculty of Management and Economics \\ Universiti Pendidikan Sultan Idris, 35900 Tanjong Malim Perak Malaysia \\ Tel: 015 48117771, Fax: 015 48117295, e-mail: azham@fpe.upsi.edu.my
}

Doi:10.5296/jpag.v5i4.8885 URL: http://dx.doi.org/10.5296/jpag.v5i4.8885

\begin{abstract}
The 1MDB stands for 1Malaysia Development Berhad. It is a company formed in 2009 by the federal government of Malaysia. 1MDB had become such a problem for many by late 2014. And today a year later the sad and debilitating saga continues unabated. The case of the $1 \mathrm{MDB}$ should be of a particular interest for students and scholars of auditing, accounting and corporate governance since it involves the following: the alleged disappearance of a huge amount of companyes funds; the apparent hiding of significant amount of real losses year after year with the accounting of paper profits originated from repeated fair revaluations of properties or other assets; the possibility of repeated cases of audit failure; the probe conducted by various parties locally which include the Office of the Auditor General; and, the lack of evidence of best practices in corporate governance being implemented since its formation. Each of these five areas of concern is laid bare in a series of five case studies where the materials come mainly from three news portals which are based inside the country: Malaysia Kini, The Malaysian Insider and Free Malaysia Today. All the published materials of concern are dated up to the end of June 2015. It is also notable that following the completion of these case studies, the work on another series of case studies shall be embarked upon. The new series shall give focus upon what has taken place since early July 2015. The intention behind the writing of these cases is to have them used in classroom discussions to help towards the emergence of Malaysia tomorrow that so many inside the country has embarked upon so that history is given as little chance as possible in repeating itself!
\end{abstract}

Keywords: $1 \mathrm{MDB}$, five cases studies, news portal, auditing, corporate financioal accounting, corporate governance 


\section{Introduction}

1MDB stands for the 1Malaysia Development Berhad. In its own words, the 1MDB had this to say about itself published as part of the media statement released in April 2013 (Gunasegaram, 2013): “1MDB is Government-owned and supported but driven by private sector thinking and practices. It strives to fulfill the aspiration of the Government with the agility of the private sector. Bonds raised are part of capital for the strategic initiatives it undertakes."

The 1MDB had its origin as Terengganu Investment Authority (TIA) which was a body intended to be a sovereign wealth fund to promote the economic interests of the state of Terengganu located in the east coast of the peninsular Malaysia (Khairie, 2015). TIA was set-up in end-February 2009 after then deputy Prime Minister Najib announced its formation three days before the 2009 by-election in Kuala Terengganu, held after the passing of incumbent Member of Parliament Razali Ismail. To start off its operation, TIA had raised some RM5 billion in a federal government-guaranteed bond issue. However, within a few months following the raising of the funds, the federal government had taken over the entity and renamed it $1 \mathrm{MDB}$.

That the 1MDB is a government owned company is uncontested. What is not settled concerns the kind of government owned company that it may be grouped under. In this regard, note the following coming from Lodin Wok Kamaruddin, chairman of the board of directors of the $1 \mathrm{MDB}$, in his press release in December 2014 (Gunasegaram, 2014a):

Contrary to claims, $1 \mathrm{MDB}$ is not a sovereign wealth fund but rather a strategic development company. In practice, this translates into a company that is independently run and funded, but one whose investment decisions are driven by the interests of the national economy. Whilst a sovereign wealth fund and a strategic development company may not sound very different, there is an important distinction between the two: whereas a sovereign wealth fund is directly funded by the government and invests on its behalf, $1 \mathrm{MDB}$ raises and invest its own capital.

It appears that Lodin had made this remark of his due to the fact that some months earlier none other than the former prime minister of Malaysia Tun Mahathir Mohamad in one of his interesting blog posts had mentioned that the 1MDB had been acting as if it was a sovereign wealth fund (Adam, 2014). Such pretension, as he put it, was clearly in contradiction to the truth since the federal government's expenditures had exceeded its income which included contribution from the nation's oil and gas company the Petronas. In short, the government had incurred budget deficits over the years leading to the conclusion that Malaysia as an oil exporter country was not like other oil exporter countries such as Kuwait and Qatar which had the sovereign wealth funds established to manage the excess income coming from their sale of hundreds of thousands of oil drums per year.

Next, he led this very fact to that which signifies the reason why the 1 MDB was a troublesome business entity to the country:

Duit untuk 1MDB bukan daripada lebihan kewangan negara, ia hutang. Berbillion ringgit 
dihutang yang menjadi penyebab hutang negara menjadi amat tinggi. Hutang oleh negara mesti dibayar. Jika tidak kita akan muflis seperti Argentina. Sebuah negara yang mengalami defisit setiap tahun tidak mungkin dapat membayar hutang sebesar ini. (The money for $1 \mathrm{MDB}$ is not from the countryes surplus. It is a debt. Billions of ringgit in debt that is added to the already-high national debt. The national debt must be paid. If not, we will be bankrupt like Argentina. A country that has been facing a deficit every year could not possibly pay off a debt this big.)

A few months later at a forum, Tun had also made similar remark on what the 1MDB truly is (Zachariah, 2015). He was quoted to say: "We should not have $1 \mathrm{MDB}$ at all. It is not a national wealth fund. We have to borrow money for it. How can you be rich if you borrow money? If you borrow some money from a chettiar (money lender), would you count yourself rich after receiving the money? No, you are poor. You are now indebted to the bank. He also claimed that he would not have set up $1 \mathrm{MDB}$ if he was still leading the nation. He was quoted to say: "So if you have excess money, then by all means have 1MDB. But if you ask me, I would not have 1MDB if I were still the PM."

1MDB had become such a problem by late 2014 as encapsulated in an interesting piece published in Kinibiz that had detailed out ten questions that those associated with the companies needed to answer (Gunasegaram, 2014b). These questions which covered matters such as the companyes loans, paper profits and investments were concluded with the following devastating remark:

If $1 \mathrm{MDB}$, our strategic investment fund, can give full and satisfactory answers to these pressing questions let them do so. Otherwise they must be simply regarded as a multi-billion ringgit renegade government company which has gone totally out of control, operating according to its whims and fancies and that is a danger to the country and its people... 1MDB must be brought under control and made responsible to the rakyat.

Half a year later later, as far as the $1 \mathrm{MDB}$ was concerned, it had failed to get better. As the former senator S. Ramakrishnan had succinctly noted on the damage that the company had entailed (Ramakrishnan, 2015):

... 1MDB sovereign fund turned out to be swelling pool that might drag down even the BN government. The complex money trails round the globe and the complex wheeling and dealing is simply complicated for even professionals... Within five years since its inception the sovereign fund accumulated 42 billion in debts and still counting. Assets pasted their expiry dates were purchased with excessive prices and prime lands allotted at nominal prices hoping for high gains on valuations. Excessive loans with high interest rates taken to finance the purchase of overpriced assets finally exposed the unsustainable business model of 1MDB. Billions of dollars transferred out with no questions from BNM to dubious accounts in Cayman Islands managed by unknown fund managers from Hong Kong makes $1 \mathrm{MDB}$ a thriller story... 1MDB will be remembered and quoted as how funds should not be managed. It is sad that a noble initiative turned out to be colossal mistake. 
But, if truth be told, $1 \mathrm{MDB}$ is just one in a series of gigantic financial scandals that the long suffering and burden carrying Malaysians have over the years been witness to as a result of the close interaction of business and politics and the consequent malfunctioning of the country's various institutions ever since the implementation of the New Economic Policy (NEP) had became distorted from the early 1980s onward. Hence, it is not the first and surely not the last of a corporate debacle of huge proportion. Note the following account of another government owned entity that had brought much losses to the country several decades earlier (Nawawi, 2014):

The 1MDB will just be like the Bank Bumiputra Malaysia Bhd (BBMB) scandal in 1983, what was then the biggest banking scandal in world history erupted in Hong Kong, when it was discovered that Bumiputra Malaysia Finance (BMF), a unit of BBMB, had lost as much as RM2.5 billion which had been siphoned off by prominent public figures into private bank accounts. Some unconfirmed reports mentioned that, this too was borrowed money; syndicated loans from several European banks. If this is true then the total loss could be more than RM5.0 billion, including paying back the loans with interests.

But compared to the BMF scandal and so many others that the country has had to suffer from over the years, the $1 \mathrm{MDB}$ may be associated with one quality not found in other cases: it is currently being investigated by authorities located in Australia, US, UK, France, Switzerland, Singapore and Hong Kong. And this is of course in addition to the fact that starting from early 2015 more and more news agencies and major newspapers from the world over have seen it fit to file damaging reports on its goings on.

\section{The Overseas' Interests in 1MDB}

As far as the investigations conducted by authorities overseas are concerned, check out the following written by a prominent leader of the Democratic Action Party Lim Kit Siang (Siang, 2015a): "The report by The Australian yesterday that a sixth foreign government, Australia, has joined five other countries, namely Switzerland, United Kingdom, Hong Kong, Singapore and United States in the ever-widening international inquiry into Malaysia's biggest scandal in history..."

As for the litany of damaging reports filed by news agencies and major newspapers from around the world on the 1MDB saga, perhaps a good selection of them as reflected in their headings is as follows:

Hunt for billions invested by 1MDB points to Australia Wall Street Journal (Nov. 3, 2015); Caribbean dealings stalk Malaysia's 1MDB Financial Times (Oct. 30, 2015); Malaysia's 1MDB scandal: Australian connection in Malaysia scandal The Australian (Oct. 24, 2015); Malaysia's 1MDB scandal: Political intrigue, billions missing and international scrutiny Wall Street Journal (Oct. 23, 2015); Malaysia's Najib Razak played key role at troubled 1MDB investment fund Wall Street Journal (Oct. 15, 2015); Malaysia's royals make unprecedented call for action on corruption Guardian (Oct. 7, 2015); Alleged scandals surrounding Malaysian PM could have several consequences The Globe and Mail (Sept. 24, 2015); Malaysia's leader, Najib 
Razak, faces U.S. corruption inquiry New York Times (Sept. 21, 2015); FBI probes Malaysia development fund Wall Street Journal (Sept. 19, 2015); Malaysia hosts anti-corruption conference as government faces its own corruption scandal Huffington Post (Sept. 11, 2015); Switzerland investigates fund executives in Malaysian corruption case New York Times (Sept. 2, 2015); Malaysia's anti-corruption efforts undermined by questions about scandal: corruption fighter Reuters (Sept. 2, 2015); Malaysia's prime minister Najib Razak dodging anti-corruption spotlight Sydney Morning Herald (Aug. 28, 2015); Malaysia's prime minister: A dead man walking? Forbes (Aug. 8, 2015); The onus is on Najib to convince the world of his innocence South China Morning Post (Aug. 2, 2015); David Cameron presses Malaysian PM on corruption claims Guardian (July 30, 2015); Malaysia cabinet reshuffle saps confidence $C N B C$ (July 30, 2015); The troubles of Malaysia's prime minister continue Economist (July 30, 2015); Facing corruption scandal, Malaysian PM fires officials investigating him Aljazeera (July 28, 2015); Singapore freezes accounts linked to 1MDB probe Financial Times (July 22, 2015); Malaysia premier Najib under fire: What you need to know Bloomberg (July 9, 2015); Can Najib Razak survive 1MDB scandal? Forbes (July 5, 2015); Twin ghosts haunt Malaysia's sovereign fund Reuters (March 12, 2015); Harrow playboy linked to troubled Malaysian fund The Sunday Times London (March 1, 2015); 1MDB's debt burden sparks fears of fallout for Malaysian economy Financial Times (February 4, 2015).

\section{MDB from July 2015 Onward}

Though only the insane ones could perhaps be able to live with penetrating attention coming from so many different parties from both inside and outside the country, by the very last quarter of 2015 there still appears to be no peaceful end in sight for the 1MDB saga. Perhaps there is not much surprise of that when in the previous quarter the various efforts to "cover up" as noted the DAP parliamentarian Lim Kit Siang had taken place in relation to the debacle (Siang, 2015b):

...the sackings of the Deputy Prime Minister, a Cabinet Minister and the Attorney-General; the three-month stoppage of Parliamentary Public Accounts Committee (PAC) investigations into 1MDB; the dissolution of the multi-agency Special Task Force on 1MDB; the suspension of The Edge publications and the abuses of power in the arrest and prosecution of $1 \mathrm{MDB}$ whistleblowers under various sections of Section 124 of Penal Code for "activities detrimental to parliamentary democracy" which were enacted to combat terrorism.

It is perhaps worth noting that a number of those acts of "cover up" mentioned by Lim Kit Siang were in fact raised in an open letter to the government of Malaysia sent a few weeks earlier in early October 2015 by the former deputy chief of the police's Special Branch Datuk Abdul Hamid Bador (Abdul-Hamid, 2015). The Malay Mail Online in its report had this to say regarding the matter ("1MDB controversy turned into", 2015):

The racially-tinged claim of a purported conspiracy to overthrow the ruling government 
is a tactic to shift the public's attention from the 1Malaysia Development Berhad (1MDB) controversy, says former deputy chief of the police's Special Branch Datuk Abdul Hamid Bador. Abdul Hamid reportedly alleged that this bid to confuse the public is meant to halt ongoing investigations on the state-owned firm... In his October 1 letter directed at the government, Abdul Hamid reportedly claimed that this was a "wicked" tactic to turn a matter of alleged "criminal breach of trust" into a "racial issue". Abdul Hamid also reportedly claimed that there have been attempts to hamper local investigations into the 1MDB controversy, including through the removal of Tan Sri Abdul Gani Patail as Attorney-General, the arrest of Malaysian Anti-Corruption Commission (MACC) officers and the disruption of investigations by Parliament's Public Accounts Committee (PAC) and a special government taskforce.

Aside from Lim Kit Siang and earlier Datuk Abdul Hamid Bador, there were of course other parties who had earlier raised their concerns over the various unsavory acts to hamper investigations on the 1MDB fiascos. Note the following which appeared in an open letter sent in late August 2015 to the prime minister by a group of 159 counselors, social workers and helping professionals ("Another professional group", 2015):

We, undersigned, a group of concerned social workers / counsellors / helping professionals, can no longer stay silent and ignorant to what is happening to our beloved homeland, Malaysia... We were first shocked by the grave allegations of financial abuse and corruption related to $1 \mathrm{MDB}$ including the transfer of RM 2.6 billion into your personal accounts. We are even more shocked now by how our media and state agencies have been deliberately sabotaged from carrying out the investigations and informing the public:

1) The blocking of independent portal Sarawak Report on July 20;

2) The three-month suspension of two financial newspapers, The Edge Weekly and The Edge Daily, beginning on July 27;

3) The abrupt removal of the Attorney General (AG) on July 27;

4) The paralysing of the Parliament's Public Accounts Committee (PAC) with the co-optation of its chair and three other members into the executive on July 28;

5) The harassments, arrests and/or investigation of senior officials in the AG's Chambers, MACC and Bank Negara Malaysia;

6) The disbandment of the Special Task Force on 1MDB - consisting of the AG'S Chambers, MACC, Bank Negara Malaysia and the Police - as revealed by the MACC on August 5.

The 1MDB scandal is cancerous to our economy and public institutions. It has eroded the confidence of both Malaysians and international community.

With Malaysians largely in teeter hook not knowing whether they are coming or going as a result of what appears to be an unending $1 \mathrm{MDB}$ nightmare, early on in the very last quarter of 
the year, to be more exact on October 6, the Conference of Malay Rulers had come out with an unprecedented statement related to the 1MDB saga (Siang, 2015b). In it, the sultans called on the government to complete the $1 \mathrm{MDB}$ investigation as soon as possible and to take "appropriate stern action" against all found to be implicated. They stressed that the findings of the 1MDB investigations to be "reported comprehensively and in a transparent manner so that the people will be convinced of the sincerity of the government which shall not at all conceal facts and the truth". They pointed out that the 1MDB scandal had resulted in a "crisis of confidence" with adverse consequences including "the plunge in the value of the Malaysian ringgit, impacting the country financial market and economic climate negative and at the same time adversely affecting the world's view of Malaysia". They reminded all leaders "to always adhere to the Rukun Negara principles of Upholding the Constitution and the Rule of Law" and "constantly ensure that justice is meted out equitably and transparently based on the law". Finally, they urged all enforcement agencies and regulatory institutions such as the Police, Malaysian Anti-Corruption Commission, Bank Negara, Attorney-General's Chambers and the Judiciary, as well as related government bodies, to be "worthy of God's trust and the people"s faith with transparency, credibility and integrity".

\section{The Five Case Studies}

By and large, the case of the $1 \mathrm{MDB}$ should be of a particular interest for students and scholars of accounting since it involves the following: the alleged disappearance of a huge amount of companyes funds; the apparent hiding of significant amount of real losses year after year with the accounting of paper profits originated from repeated fair revaluations of properties or other assets; the possibility of repeated cases of audit failure; the probe conducted by various parties locally which include the Office of the Auditor General; and, the lack of evidence of best practices in corporate governance being implemented since its formation. Each of these five areas of concern is laid bare in a series of five case studies.

It is notable that all the details found in these case studies are derived from selected materials published mainly in three news portals which are based inside the country: MalaysiaKini, The Malaysian Insider and Free Malaysia Today. All the published materials of concern are dated up to the end of June 2015. It is also notable that following the completion of these case studies, the work on another series of case studies shall be embarked upon. The new series shall give focus upon what has taken place since early July 2015.

Also, it needs to be pointed out that the present series of case studies is nothing but an initial and tentative effort of studying an on going development that may have a huge impact to the country for years to come. Future series of the same entity may be strengthened with the use of data derived from methods such as interview and analyses of financial statements and published materials of overseas sources. $1 \mathrm{MDB}$ is nonetheless only one among a number of subject matters of interest for case writing which is concerned with several types of entities whose spectrum of conducts in the field of business, accounting or governance have brought the attention of many to themselves. The intention behind the writing of these cases is to have them used in classroom discussions to help towards the emergence of Malaysia tomorrow that so many inside the country has embarked upon so that history is given as little 
chance as possible in repeating itself!

\section{References}

Abdul-Hamid, B. (2015, October 1). Surat terbuka kepada kerajaan. Retrieved October 5, 2015, from http://dinturtle.blogspot.my/2015/10/hot-surat-terbuka-abdul-hamid-bador.html

Adam, A.B. (2014, September 10). 1MDB: Tun M Bidas Kenyataan Salleh. Free Malaysia Today. Retrieved from http://www.freemalaysiatoday.com/category/bahasa/2014/09/10/tun-m-membidas-kenyataansalleh/

Another professional group voices out against Najib (2015, August 25). Malaysiakini. Retrieved from https://www.malaysiakini.com/news/309836

Gunasegaram, P. (2013, April 24). 1MDB revisited: A new enigmatic name emerges - SRC. Kinibiz Online. Retrieved from http://www.kinibiz.com/story/issues/16932/1mdb-revisited-a-new-enigmatic-name-emerges-s rc.html

Gunasegaram, P. (2014a, December 29). 1MDB's Lodin answers nothing. Kinibiz Online. Retrieved from http://www.kinibiz.com/story/tigertalk/131400/1mdb\%E2\%80\%99s-lodin-answers-nothing.ht $\mathrm{ml}$ ?utm_source=applet_mkinicom\&utm_medium=web\&utm_campaign=mkinicom

Gunasegaram, P. (2014b, November 5). 1MDB: A renegade that has to be brought under control. Kinibiz Online. Retrieved from http://www.kinibiz.com/story/tigertalk/118690/1 mdb-a-renegade-that-has-to-be-brought-unde r-control.html

Khairie, H. (2015, March 16). „Daim cautioned Najib over 1MDB“e. Kinibiz Online. Retrieved from

http://www.kinibiz.com/story/corporate/154012/\%E2\%80\%9Cdaim-cautioned-najib-over-1m $\mathrm{db} \% \mathrm{E} 2 \% 80 \% 9 \mathrm{D} . \mathrm{htm}$ ? utm_source=applet_mkinicom\&utm_medium $=$ web\&utm_campaign $=$ mkinicom

Nawawi, M. (2014, December 6). 1MDB will morph into disaster, Najib has no plan B. The Malaysian Insider. Retrieved from http://www.themalaysianinsider.com/sideviews/article/1mdb-will-morph-into-disaster-najib-h as-no-plan-b-nawawi-mohamad

$1 \mathrm{MDB}$ controversy turned into racial conspiracy to divert attention, says former Special Branch deputy chief (2015, October 4). The Malay Mail. Retrieved from http://www.themalaymailonline.com/malaysia/article/1mdb-controversy-turned-into-racial-co nspiracy-to-divert-attention-says-for

Ramakrishnan, S. (2015, March 19). 1Malaysia initiatives finally drowned in debts. The 


\section{Macrothink}

Journal of Public Administration and Governance

ISSN 2161-7104 2015, Vol. 5, No. 4

Malaysian

Insider.

Retrieved

from

http://www.themalaysianinsider.com/sideviews/article/1malaysia-initiatives-finally-drownedin-debts-s.-ramakrishnan

Siang, L.K. (2015, October 25a). Najib's 2016 Budget made history as a budget which could not generate any budget euphoria as it was snuffed out within seconds of delivery by phalanx of Opposition MPs standing up and displaying "Mana RM2.6 billion" placard. Retrieved from

http://blog.limkitsiang.com/2015/10/25/najibs-2016-budget-made-history-as-a-budget-whichcould-not-generate-any-budget-euphoria-as-it-was-snuffed-out-within-seconds-of-delivery-by -phalanx-of-opposition-mps-standing-up-and-displayi/

Siang, L.K. (2015, October 29b). Najib government too "economical with the truth" when it would not clarify after two weeks of Parliament whether Muhyiddin was right in his last speech as DPM three months ago that 1MDB scandal had mushroomed from RM42 billion to over RM50 billion. Retrived from http://blog.limkitsiang.com/2015/10/29/najib-government-too-economical-with-the-truth-whe n-it-would-not-clarify-after-two-weeks-of-parliament-whether-muhyiddin-was-right-in-his-la st-speech-as-dpm-three-months-ago-that-1md/

Zachariah, E. (2015, February 12). No 1MDB if I were still PM, says Dr. M. The Malaysian Insider. Retrieved from http://www.themalaysianinsider.com/about/ 